\title{
Urokinase-type plasminogen activator and arthritis progression: role in systemic disease with immune complex involvement
}

Andrew D Cook ${ }^{1,2^{*}}$, Christine M De Nardo ${ }^{1,2}$, Emma L Braine ${ }^{1,2}$, Amanda L Turner ${ }^{1,2}$, Ross Vlahos ${ }^{1,2}$, Kerrie J Way ${ }^{1,2}$, S Kaye Beckman ${ }^{1,2}$, Jason C Lenzo ${ }^{1,2}$, John A Hamilton ${ }^{1,2}$

\begin{abstract}
Introduction: Urokinase-type plasminogen activator (u-PA) has been implicated in fibrinolysis, cell migration, latent cytokine activation, cell activation, T-cell activation, and tissue remodeling, all of which are involved in the development of rheumatoid arthritis. Previously, u-PA has been reported to play a protective role in monoarticular arthritis models involving mBSA as the antigen, but a deleterious role in the systemic polyarticular collageninduced arthritis (CIA) model. The aim of the current study is to determine how u-PA might be acting in systemic arthritis models.
\end{abstract}

Methods: The CIA model and bone marrow chimeras were used to determine the cellular source of u-PA required for the arthritis development. Gene expression of inflammatory and destructive mediators was measured in joint tissue by quantitiative PCR and protein levels by ELISA. The requirement for u-PA in the type II collagen mAbinduced arthritis (CAIA) and K/BxN serum transfer arthritis models was determined using $\mathrm{u}-\mathrm{PA}^{-/}$mice. Neutrophilia was induced in the peritoneal cavity using either ovalbumin/anti-ovalbumin or the complement component C5a.

Results: $\mathrm{u}-\mathrm{PA}$ from a bone marrow-derived cell was required for the full development of CIA. The disease in u-PA ${ }^{-1-}$ mice reconstituted with bone marrrow from C57BL/6 mice was indistinguishable from that in C57BL/6 mice, in terms of clincal score, histologic features, and protein and gene expression of key mediators. u-PA ${ }^{-/}$mice were resistant to both CAIA and K/BxN serum transfer arthritis development. u-PA ${ }^{-/-}$mice developed a reduced neutrophilia and chemokine production in the peritoneal cavity following ovalbumin/anti-ovalbumin injection; in contrast, the peritoneal neutrophilia in response to C5a was u-PA independent.

Conclusions: $\mathrm{U}-\mathrm{PA}$ is required for the full development of systemic arthritis models involving immune complex formation and deposition. The cellular source of U-PA required for CIA is bone marrow derived and likely to be of myeloid origin. For immune complex-mediated peritonitis, and perhaps some other inflammatory responses, it is suggested that the u-PA involvement may be upstream of C5a signaling.

\section{Introduction}

Urokinase-type plasminogen activator $(\mathrm{u}-\mathrm{PA})$ is a serine protease that, along with tissue-type plasminogen activator (t-PA), cleaves plasminogen to form plasmin [1]. The plasminogen activator (PA)/plasmin system has been implicated in the following processes in both physiology and pathology: fibrinolysis, cell migration, latent cytokine activation, cell activation via u-PA receptor (u-PAR),

\footnotetext{
* Correspondence: adcook@unimelb.edu.au

${ }^{1}$ Arthritis and Inflammation Research Centre, Department of Medicine, The University of Melbourne, Parkville, Melbourne, Victoria 3010, Australia
}

T-cell activation, and tissue remodeling (directly or indirectly via matrix metalloprotease (MMP) activation) (reviewed in [1,2]).

Rheumatoid arthritis is a chronic systemic inflammatory disease of unknown etiology, characterized by synovial hyerplasia, infiltration of inflammatory cells, intra-articular fibrin deposition and erosion of cartilage and bone. Enhanced u-PA and reduced t-PA activity in the synovium have been associated with rheumatoid arthritis severity [3]. Increased levels of u-PAR, and the PA inhibitors PAI-1 and PAI-2, are also found in 
rheumatoid arthritis tissue [3]. Several different cell types present in arthritic joints can produce PAs and their inhibitors in vitro, including in response to inflammatory cytokines [4-11]. We and other workers have previously reported that $\mathrm{u}-\mathrm{PA}$ plays a protective role in the antigen-induced arthritis (AIA) model [12] and the mBSA/IL-1 monoarticular arthritis model [13], with uPA gene-deficient $\left(\mathrm{u}-\mathrm{PA}^{-1}\right)$ mice developing more severe disease associated with increased intra-articular fibrin deposition. In the chronic systemic collagen-induced arthritis (CIA) model, however, we [14] and other workers [15] have found that $\mathrm{u}-\mathrm{PA}$ was deleterious, with $\mathrm{u}-\mathrm{PA}^{-1-}$ mice developing very mild disease and little fibrin deposition. In addition, the $\mathrm{T}$-cell proliferative response to type II collagen (CII) was reduced in $\mathrm{u}-\mathrm{PA}^{-1-}$ mice, although the antibody response to $\mathrm{CII}$ was normal [14]. Information on why u-PA depletion has differing outcomes in these various arthritis models is lacking but is essential if u-PA targeting is to be considered as a therapeutic strategy in rheumatoid arthritis and other inflammatory conditions.

In order to examine how u-PA might be acting in the systemic arthritis models, the following parameters were assessed: the cellular source of u-PA required for CIA development; inflammatory and destructive mediator expression in the joints of C57BL/6 mice and $\mathrm{u}-\mathrm{PA}^{-/-}$ mice following CIA development; the requirement for $\mathrm{u}-\mathrm{PA}$ in the development of the CII mAb-induced arthritis model (CAIA) and the $\mathrm{K} / \mathrm{BxN}$ serum transfer model of arthritis, both of which do not require $B$ cells or $\mathrm{T}$ cells, at least for the initiation of disease [16-18]; and the requirement for $\mathrm{u}-\mathrm{PA}$ in the development of immune complex-mediated neutrophilia in the peritoneal cavity. We show that u-PA produced by a bone marrow-derived cell is important for the full development of CIA; many inflammatory and destructive mediators are increased in the joints of C57BL/6 mice but not of $\mathrm{u}-\mathrm{PA}^{-1-}$ mice following CIA development; $\mathrm{u}-\mathrm{PA}^{-/-}$ mice are essentially resistant to both CAIA and the $\mathrm{K} /$ BxN serum transfer model of arthritis; and immune complex-mediated neutrophilia and chemokine production in the peritoneal cavity is u-PA dependent, whereas C5a-mediated neutrophilia is not, suggesting u-PA is acting upstream of C5a signaling.

\section{Materials and methods \\ Mice}

The $\mathrm{u}-\mathrm{PA}^{-/-}$mice, provided by Dr P Carmeliet (University of Leuven, Belgium), were backcrossed onto the C57BL/6 background for 11 generations. C57BL/6 CD45 congenic mice, expressing the Ly5.1 allotype, were obtained from Walter and Eliza Hall Institute Animal Supplies (Parkville, Victoria, Australia). All strains were bred in our onsite animal facility, fed standard rodent chow and water ad libitum, and housed in sawdust-lined cages in groups of five. Mice of both sexes, 8 to 12 weeks of age, were used in all experiments. All experiments were approved by The Royal Melbourne Hospital Research Foundation Animal Ethics Committee.

\section{Bone marrow transplantation}

The $\mathrm{u}-\mathrm{PA}^{-1-}$ or $\mathrm{C} 57 \mathrm{BL} / 6$ recipient mice received total body irradiation (two exposures $\times 5.5 \mathrm{~Gy}, 3$ hours apart). Bone marrow cells were harvested from the femurs and tibiae of $\mathrm{C} 57 \mathrm{BL} / 6$ or $\mathrm{u}-\mathrm{PA}^{-/}$donor mice expressing the Ly5.1 allotype of CD45. Recipient mice (expressing the Ly5.2 allotype of CD45) were injected intravenously with $5 \times 10^{6}$ bone marrow cells. Effective bone marrow reconstitution was determined by flow cytometry analysis of peripheral blood leukocytes 6 weeks later using the different congenic CD45 allotypes (Ly5.1 and Ly5.2). Six weeks after irradiation, $95 \pm 1 \%$ of circulating leukocytes expressed the phenotypic marker of the donor bone marrow.

\section{Collagen-induced arthritis}

Mice were immunized intradermally in the base of the tail with $100 \mu \mathrm{g}$ chick CII (Sigma, St Louis, MO, USA), emulsified in an equal volume of complete Freund's adjuvant containing $5 \mathrm{mg} / \mathrm{ml}$ heat-killed Mycobacterium tuberculosis (H37 Ra; Difco, Detroit, MI, USA). This procedure was repeated as a boost 21 days later, as previously published [14].

Animals were assessed for redness and swelling of limbs and a clinical score was allocated for each limb using an established scoring system with slight modifications [14] as follows: $0=$ normal; $1=$ slight swelling and/or erythema; 2 = extensive swelling and/or erythema; 3 = severe swelling; 4 = rigidity. Severity of arthritis is expressed in terms of the mean clinical score (range 0 to 16 per mouse).

\section{Type II collagen mAb-induced arthritis model}

The anti-CII mAb-producing hybridomas for M2139 and CIIC1 were a gift from Prof. R Holmdahl (Karolinska Institute, Stockholm, Sweden). The cocktail of M2139 and CIIC1 mAbs was prepared by mixing equal concentrations of each of the antibody, and mice were then injected intravenously with $4.5 \mathrm{mg}$ mAb cocktail on days 0 and 1 . On day 5 , mice received intraperitoneally $50 \mu \mathrm{g}$ lipopolysaccharide (Escherichia coli serotype 0127:B8; Sigma-Aldrich), 5 mg Pam-3-Cys (EMC Microcollections, Tübingen, Germany), or PBS. Mice were scored daily, using the same scoring system as for the CIA model. 
$\mathrm{K} / \mathrm{BxN}$ serum transfer model of arthritis

$\mathrm{K} / \mathrm{BxN}$ mice were bred as described previously [19]. Serum was collected up to 12 weeks of age and stored at $-80^{\circ} \mathrm{C}$. Serum $(50 \mu \mathrm{l}$ in $150 \mu \mathrm{l} \mathrm{PBS})$ was injected intraperitoneally on days 0 and 2. Mice were scored daily, using the same scoring system as for the CIA model.

\section{Immune complex-mediated neutrophilia}

Fifty microliters of chicken egg albumin (ovalbumin, 20 $\mathrm{mg} / \mathrm{kg}$ body weight; Sigma) was injected intravenously followed by intraperitoneal injection of $1 \mathrm{ml}$ rabbit polyclonal IgG rich in antibody to chicken egg albumin (anti-ovalbumin, $800 \mu \mathrm{g} /$ mouse; Sigma), as previously described [20]. Cells were harvested 4 hours later by lavage with $5 \mathrm{ml}$ ice-cold, sterile PBS. Total and differential cell counts (Diff-Quik; Lab Aids, Narrabeen, NSW, Australia) were performed on the peritoneal exudate cells $[21,22]$.

In certain experiments, C5a (1.25 $\mu \mathrm{g}$; HyCult Biotechnology, Uden, The Netherlands) was given intraperitoneally alone or administered together with the anti-ovalbumin, as above. In these experiments, cells were harvested 2 hours later.

\section{Histology}

At termination following arthritis induction, the rear limbs and ankles were removed, fixed, decalcified, and paraffin embedded, as previously described [14]. Frontal sections $(5 \mu \mathrm{m})$ were stained with either $\mathrm{H} \& \mathrm{E}$ to examine joint architecture or with safranin $\mathrm{O}$, fast green and hematoxylin for proteoglycan loss, and were evaluated without knowledge of the experimental groups, using the histologic assessment as published [14]. Briefly, infiltration of cells, cartilage damage and bone erosions were all scored separately from 0 (normal) to 3 (severe), and proteoglycan loss was scored from 0 (normal) to 3 (complete loss of staining). These scores were added to give an overall histologic score out of 12 .

\section{Detection of fibrin(ogen) by immunohistochemistry}

Fibrin(ogen) deposition was identified in rear limbs as before [14]. Briefly, paraffin-embedded sections were deparaffinized, incubated with $1 \%(\mathrm{w} / \mathrm{v}) \mathrm{BSA}$ and $5 \%(\mathrm{w} / \mathrm{v})$ skim milk powder for 1 hour, and then stained with a goat anti-mouse fibrinogen/fibrin antibody (Accurate Chemical \& Scientific, Westbury, NY, USA) overnight at $4^{\circ} \mathrm{C}$. Endogenous peroxidase activity was blocked with $0.3 \%(\mathrm{v} / \mathrm{v})$ $\mathrm{H}_{2} \mathrm{O}_{2}$ (Sigma) in methanol. Following washing, sections were incubated with a biotinylated donkey anti-goat IgG (Jackson ImmunoResearch, West Grove, PA, USA), followed by a streptavidin-peroxidase conjugate (BD
Pharmingen, San Diego, CA, USA). Peroxidase activity was demonstrated by incubation with 3-amino-9-ethylcarbazole (Sigma). Sections were counterstained with hematoxylin.

\section{Preparation of joint tissue washouts}

Following sacrifice, the tendons and synovium from the ankle joints of the hind limbs were dissected free from the surrounding tissue and washed in $200 \mu \mathrm{l}$ DMEM, supplemented with HEPES $(20 \mathrm{mM})$, L-glutamine (2 $\mathrm{mM})$, and penicillin $(50 \mathrm{U} / \mathrm{ml}) /$ streptomycin $(50 \mu \mathrm{g} / \mathrm{ml})$, and were incubated for 1 hour at room temperature to allow the elution of cytokines [14]. Supernatants were then removed and stored at $-20^{\circ} \mathrm{C}$ until assayed.

\section{Cytokine ELISAs}

TNF $\alpha$ and IL-1 $\beta$ levels were measured in ankle joint tissue washouts by ELISA (OptEIA ELISA kits; BD Pharmingen), as outlined previously [14]. TNF $\alpha$ and IL-1 $\beta$ ELISAs were sensitive down to 5 and $3 \mathrm{pg} / \mathrm{ml}$, respectively. Keratinocyte-derived chemokine $(\mathrm{KC})$ and macrophage inflammatory protein-2 (MIP-2) levels were measured in the peritoneal exudate fluid by ELISA (DuoSet; R\&D Systems, Minneapolis, MN, USA), according to the manufacturer's instructions: $\mathrm{KC}$ and MIP-2 ELISAs were sensitive down to $2 \mathrm{pg} / \mathrm{ml}$.

\section{MMP-9 expression in joint tissue washouts}

Zymography was used to assess protease expression in joint tissue washouts [23]. Briefly, joint washouts from mice with the same arthritic score were pooled and concentrated. SDS-PAGE mini-gels (10\%) were prepared with the incorporation of gelatin $(2 \mathrm{mg} / \mathrm{ml}$; Labchem, Pittsburgh, PA, USA) before casting. The joint washouts $(20 \mu \mathrm{l})$ were run into gels at a constant voltage of $200 \mathrm{~V}$ under nonreducing conditions. When the dye front reached the bottom, gels were removed and washed twice for 15 minutes in $2.5 \%$ Triton X-100 and incubated at $37^{\circ} \mathrm{C}$ overnight in zymography buffer $(50 \mathrm{mM}$ Tris- $\mathrm{HCl}\left(\mathrm{pH} \mathrm{7.5)}, 5 \mathrm{mM} \mathrm{CaCl}, 1 \mathrm{mM} \mathrm{ZnCl}_{2}\right.$ and $0.01 \% \mathrm{NaN}_{3}$ ). The gels were then stained for 45 minutes with Coomassie Brilliant Blue R-250 (Sigma) and extensively destained. Following destaining, zones of enzyme activity appeared clear against the Coomassie Blue background.

\section{Quantitative PCR analysis of gene expression}

Quantitative PCR was performed as before [24]. Briefly, joints were crushed, RNA was extracted using the RNeasy Mini Kit (Qiagen, Valencia, CA, USA) and cDNA was prepared. Quantitative PCR was performed 
using Predeveloped TaqMan gene expression assays for TNF $\alpha$, IL-1 $\beta$, IL-6, MCP-1, t-PA, u-PA, u-PAR, MMP3, MMP-9, MMP-13, ADAMTS-4 and ADAMTS-5 (Applied Biosystems, Foster City, CA, USA), and was read on an ABI Prism $7900 \mathrm{H}$ sequence detection system, followed by analysis using ABI Prism SDS 2.1 software. The TATA-binding protein (GeneWorks, Thebarton, SA, Australia) was used as the control gene. The comparative threshold method for relative quantification was used, and results are expressed as relative gene expression for each target gene.

\section{Statistical analysis}

For clinical and histologic scores and cytokine levels, the Mann-Whitney two-sample rank test was used to determine the level of significance between two experimental groups. For peritonitis and gene expression studies, an unpaired Student's $t$ test was used; values are expressed as the mean \pm standard error of the mean. $P \leq 0.05$ was considered statistically significant.

\section{Results}

Bone marrow cell-derived $\mathrm{u}-\mathrm{PA}$ is required for full induction of collagen-induced arthritis

Based on in vitro studies, several different cell types present in arthritic joints have been proposed to be potential sources of u-PA [10]. To determine the cellular source of u-PA important for the development of arthritis, bone marrow chimera experiments were performed followed by the induction of CIA.

u-PA production by bone marrow-derived cell(s) is sufficient C57BL/6 mice developed CIA with an incidence of $80 \%$ (eight out of 10 mice) and average maximum clinical severity of $4.1 \pm 1.2$. C57BL/6 sham chimeras (C57 $\rightarrow$ C57) developed disease of a similar incidence $(92 \%, 11$ out of 12 mice) and severity (Figure 1a), with an average clinical severity of $4.4 \pm 1.4$, indicating that bone marrow transplantation per se did not affect the disease development. u-PA ${ }^{-1-}$ mice developed mild CIA (Figure 1a), with a cumulative incidence of $75 \%$ (six out of eight mice) and mean severity of $1.5 \pm 0.6(P<0.05$ compared

(a)

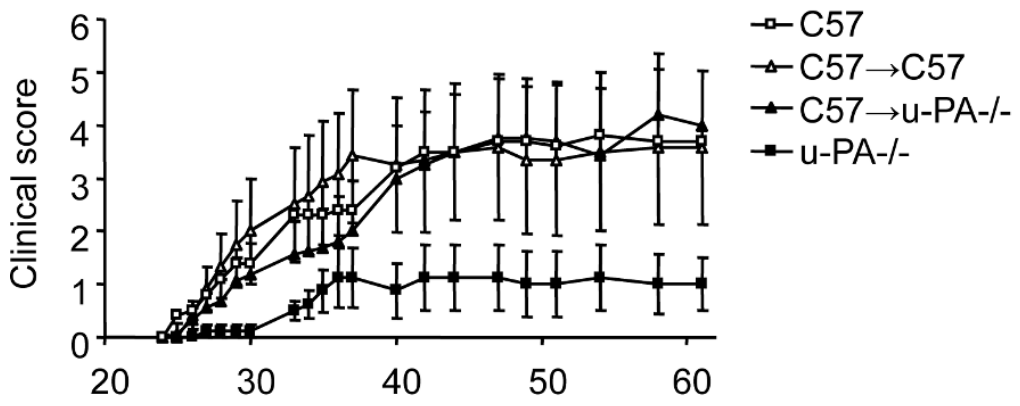

Days post immunization

(b)

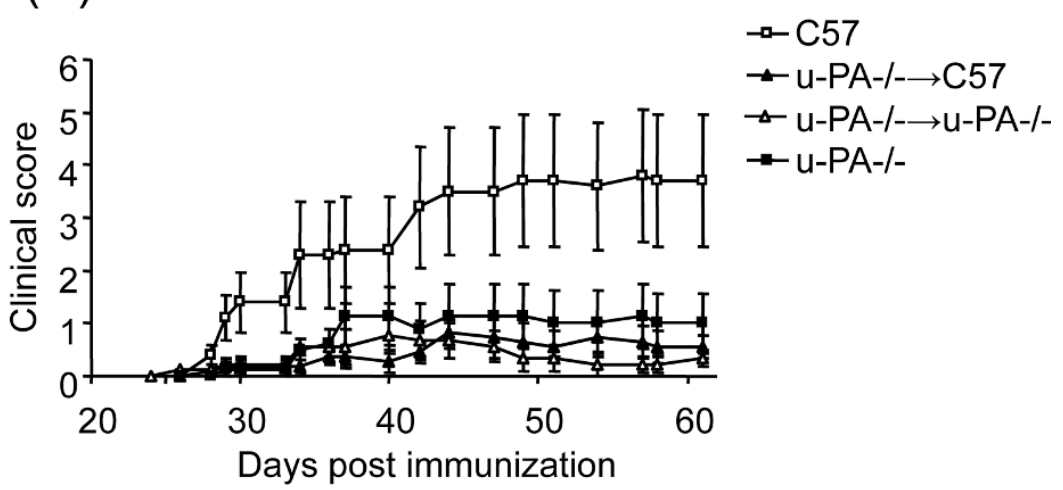

Figure 1 Collagen-induced arthritis development in C57BL/6 and u-PA ${ }^{-/-}$chimeric mice. Urokinase-type plasminogen activator (u-PA) production by bone marrow-derived cells is required for full expression of collagen-induced arthritis (CIA). (a) Severity (mean clinical score for all mice \pm standard error of the mean) for $\mathrm{C} 57(\mathrm{n}=10), \mathrm{C} 57 \rightarrow \mathrm{C} 57(\mathrm{n}=12), \mathrm{C} 57 \rightarrow \mathrm{u}-\mathrm{PA}^{-1-}(\mathrm{n}=16)$ and $\mathrm{u}^{-P A^{-1}}(\mathrm{n}=8)$ mice. $P<0.05, \mathrm{C} 57 \rightarrow \mathrm{u}-$

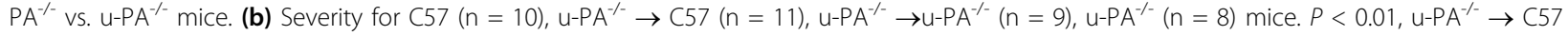
vs. C57 mice. 
with C57BL/6 mice), as previously reported [14]. Adoptively transferring bone marrow cells from C57BL/6 mice to irradiated $\mathrm{u}-\mathrm{PA}^{-1-}$ mice $\left(\mathrm{C} 57 \rightarrow \mathrm{u}-\mathrm{PA}^{-1-}\right)$ led to the development of CIA that was indistinguishable from that induced in C57BL/6 mice (Figure 1a), with a cumulative incidence of $69 \%$ (11 out of 16 mice) and a mean maximum clinical score of $4.9 \pm 1.2$. The severity of arthritis was significantly greater in these $\mathrm{C} 57 \mathrm{BL} / 6 \rightarrow \mathrm{u}$ $\mathrm{PA}^{-1-}$ chimeras compared with $\mathrm{u}-\mathrm{PA}^{-1-}$ mice $(P<0.05)$. $\mathrm{u}$-PA produced by a bone marrow-derived cell(s) is thus sufficient for the full induction of CIA.

\section{$u-P A$ production by non-bone marrow-derived cell(s) is not sufficient}

To determine whether u-PA derived from a non-bone marrow cell(s) could also restore disease in $\mathrm{u}-\mathrm{PA}^{-/-}$ mice, the reverse chimera experiment was performed whereby bone marrow cells from $\mathrm{u}-\mathrm{PA}^{-/-}$mice were transferred to irradiated C57BL/6 mice (u-PA ${ }^{-1-} \rightarrow$ C57). $\mathrm{u}-\mathrm{PA}^{-1-}$ sham chimeras, in which $\mathrm{u}-\mathrm{PA}^{-1-}$ bone marrow was transferred to irradiated $\mathrm{u}-\mathrm{PA}^{-1-}$ mice $\left(\mathrm{u}-\mathrm{PA}^{-1-} \rightarrow \mathrm{u}-\right.$ $\mathrm{PA}$ ), developed disease with a similar severity (Figure $1 \mathrm{~b}$ ) and incidence as $\mathrm{u}-\mathrm{PA}^{-1-}$ mice; five out of nine (56\%) of the sham chimeras developed disease with a low severity of $1.2 \pm 0.4$. The $\mathrm{u}-\mathrm{PA}^{-1-} \rightarrow \mathrm{C} 57$ chimeras developed disease similar to $\mathrm{u}-\mathrm{PA}^{-/-}$mice (Figure $1 \mathrm{~b}$ ); $56 \%$ (seven out of 11) of the chimeras developed arthritis with a mean maximum clinical score of $1.2 \pm 0.4$. The severity of arthritis was significantly milder in these $\mathrm{u}-\mathrm{PA}^{-1-} \rightarrow$ C57 chimeras compared with $\mathrm{C} 57$ mice $(P<$ $0.01)$. $\mathrm{u}-\mathrm{PA}$ produced by a non-bone cell(s) is thus not sufficient for full induction of CIA.

Histologic features of arthritis are similar in CIA-susceptible chimeric mice as in C57BL/6 mice

By histology, the CIA in C57 $\rightarrow$ C57 chimeras (Figure 2) and C57BL/6 mice (data not shown) $[14,25,26]$ were indistinguishable in terms of cell infiltration, cartilage destruction, proteoglycan depletion and bone erosions. Likewise, the $\mathrm{C} 57 \rightarrow \mathrm{u}-\mathrm{PA}^{-1-}$ chimeras, which were susceptible to arthritis, were similar in terms of the histologic features to the $\mathrm{C} 57 \rightarrow \mathrm{C} 57$ chimeras (Figure 2). In contrast, $\mathrm{u}-\mathrm{PA}^{-1-} \rightarrow \mathrm{C} 57$ chimeras, which developed significantly milder disease compared with C57BL/6 mice, showed minimal histologic changes which were similar to those observed in u-PA ${ }^{-1-} \rightarrow \mathrm{u}-\mathrm{PA}^{-1-}$ mice (Figure 2).

Inflammatory mediator production and gene expression in joints are increased in CIA-susceptible C57BL/6 mice compared with $\mathrm{CIA-resistant} \mathrm{U}-\mathrm{PA}^{-/-}$mice

Our earlier study showed that TNF and IL- $1 \beta$ levels were increased in joint washouts from CIA-susceptible wildtype mice compared with CIA-resistant $\mathrm{u}-\mathrm{PA}^{-1-}$ mice [14]. TNF and IL-1 $\beta$ levels in joint washouts were significantly higher in the arthritic C57 $\rightarrow$ C57 and C57 $\rightarrow$ $\mathrm{u}-\mathrm{PA}^{-1-}$ mice compared with $\mathrm{u}-\mathrm{PA}^{-1-} \rightarrow \mathrm{u}-\mathrm{PA}^{-1-}$ and $\mathrm{u}-\mathrm{PA}^{-1-} \rightarrow \mathrm{C} 57$ mice (Figure 3a). Likewise, gene expression of TNF and IL- $1 \beta$, as well as of IL- 6 and MCP-1, in joints was increased in arthritic C57BL/6 and $\mathrm{C} 57 \rightarrow \mathrm{u}-\mathrm{PA}^{-1-}$ chimeric mice compared with $\mathrm{u}-\mathrm{PA}^{-1-}$ mice following CIA development $(P<0.05$ for each mediator, Figure $3 \mathrm{~b})$. Gene expression levels of joint t-PA and $\mathrm{u}$-PA were also increased in arthritic C57BL/6 mice compared with $\mathrm{u}-\mathrm{PA}^{-1-}$ mice (Figure 3c); however, mRNA levels in joints from arthritic $\mathrm{C} 57 \rightarrow \mathrm{u}-\mathrm{PA}^{-/-}$chimeric mice were intermediate between the increased levels in arthritic C57BL/6 mice and levels in non-arthritic u-PA ${ }^{-1-}$ mice (Figure 3c). For u-PA, this could be explained by the fact that $\mathrm{u}-\mathrm{PA}$ was only expressed in bone marrowderived cells in $\mathrm{C} 57 \rightarrow \mathrm{u}-\mathrm{PA}^{-1-}$ chimeric mice. u-PAR gene expression was increased in both arthritic C57BL/6 and $\mathrm{C} 57 \rightarrow \mathrm{u}-\mathrm{PA}^{-1-}$ chimeric mice compared with $\mathrm{u}-$ $\mathrm{PA}^{-1-}$ mice $\left(P<0.01, \mathrm{C} 57\right.$ vs. $\mathrm{u}-\mathrm{PA}^{-1-}$ mice; $P<0.05$, C57 $\rightarrow \mathrm{u}-\mathrm{PA}^{-1-}$ vs. u-PA ${ }^{-1-}$ mice) (Figure $3 \mathrm{c}$ ), despite the difference in $\mathrm{u}-\mathrm{PA}$ expression.

MMP-3, MMP-9 and MMP-13 mRNA expression levels were all increased in joints from arthritic C57BL/6 mice $(P<0.001$, MMP-3; $P<0.01$, MMP-9; $P<0.0001$, $\mathrm{MMP}-13)$ and $\mathrm{C} 57 \rightarrow \mathrm{u}-\mathrm{PA}^{-1-}$ chimeric mice $(P<$ 0.0001, MMP-3; $P<0.05$, MMP-9; $P<0.05$, MMP-13) compared with those in $\mathrm{u}-\mathrm{PA}^{-/-}$mice (Figure 4a). By zymography, MMP-9 activity was increased in joint washouts from arthritic C57BL/6 mice with increasing arthritis severity (Figure 4b). This activity in joint washouts from $\mathrm{u}-\mathrm{PA}^{-1-}$ mice was similar to that in C57BL/6 mice with no arthritis, in line with these mice having no to very mild disease (Figure $4 \mathrm{~b}$ ). ADAMTS-4 mRNA expression levels, but not those for ADAMTS-5, were increased in both arthritic C57BL/6 mice $(P<0.001$, ADAMTS-4) and $\mathrm{C} 57 \rightarrow \mathrm{u}-\mathrm{PA}^{-1-}$ chimeric mice $(P<$ 0.05 , ADAMTS-4) compared with those in $\mathrm{u}-\mathrm{PA}^{-1-}$ mice (Figure 4a).

The arthritis that develops in $\mathrm{C} 57 \rightarrow \mathrm{u}-\mathrm{PA}^{-1-}$ chimeric mice is thus indistinguishable from the arthritis seen in C57BL/6 mice, both in terms of histologic features of disease, as well as the protein and gene expression of important inflammatory and destructive mediators.

\section{$\mathrm{u}-\mathrm{PA}^{-/-}$mice are resistant to type II collagen mAb-induced arthritis}

We previously found [14] a reduced proliferative T-cell response to CII stimulation in vitro in CII-primed $\mathrm{u}$ $\mathrm{PA}^{-1-}$ mice compared with CII-primed C57BL/6 mice even though the antibody response to CII was similar between the strains, suggesting normal immune complex formation in $\mathrm{u}-\mathrm{PA}^{-/-}$mice following CIA induction. In order to determine whether the reduced antigenspecific $\mathrm{T}$-cell response could explain the mild CIA development in $\mathrm{u}-\mathrm{PA}^{-1-}$ mice, the immune complexmediated CAIA model [27] was initiated in $\mathrm{u}-\mathrm{PA}^{-/-}$and C57BL/6 mice. In contrast to CIA, this model bypasses 

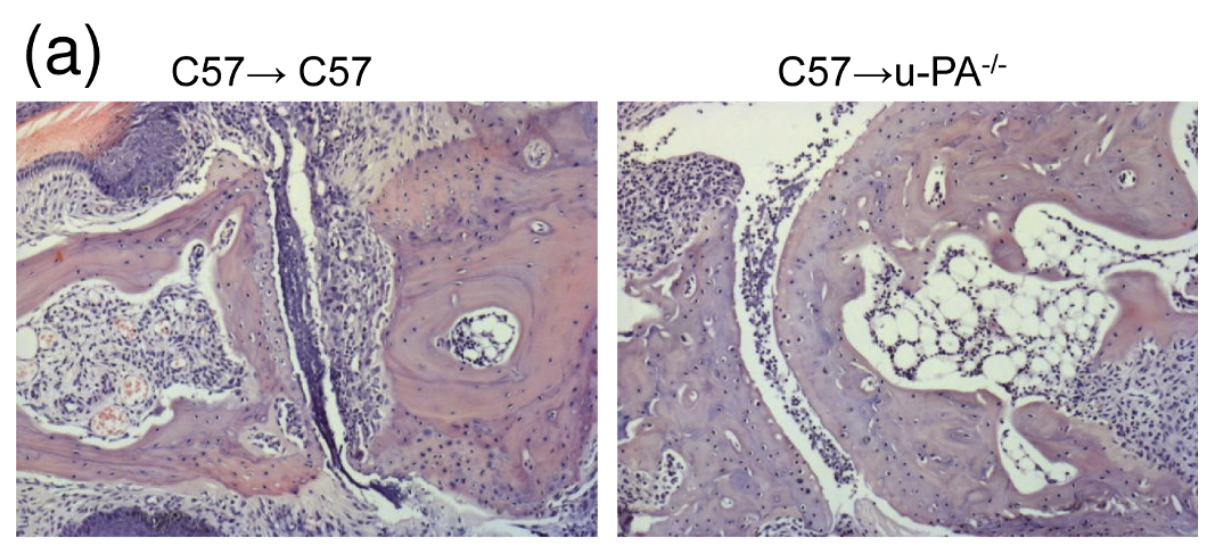

$$
\mathrm{u}-\mathrm{PA}^{-/-} \rightarrow \mathrm{C} 57
$$

$$
\mathrm{u}-\mathrm{PA}^{-1-} \rightarrow \mathrm{u}-\mathrm{PA}^{-/-}
$$
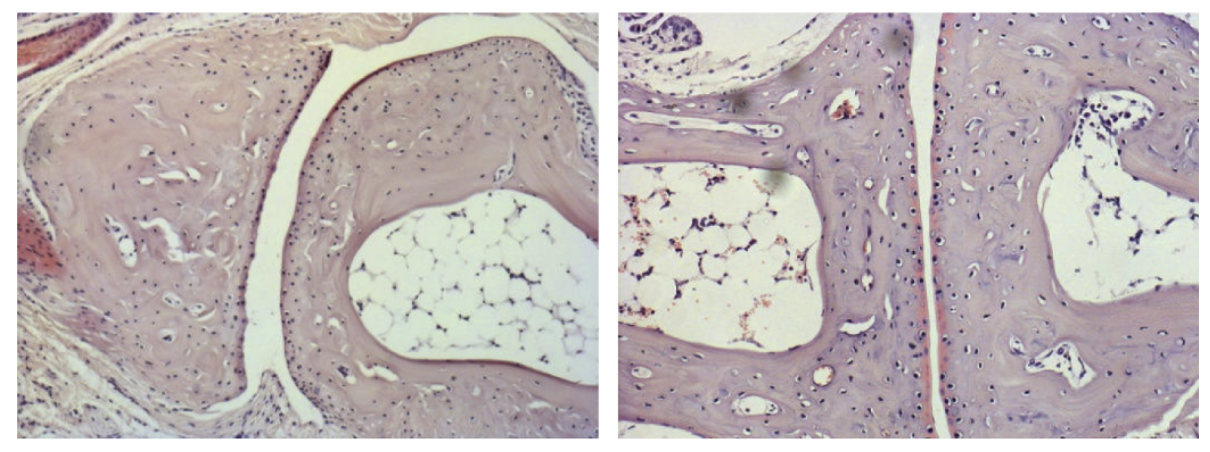

(b)

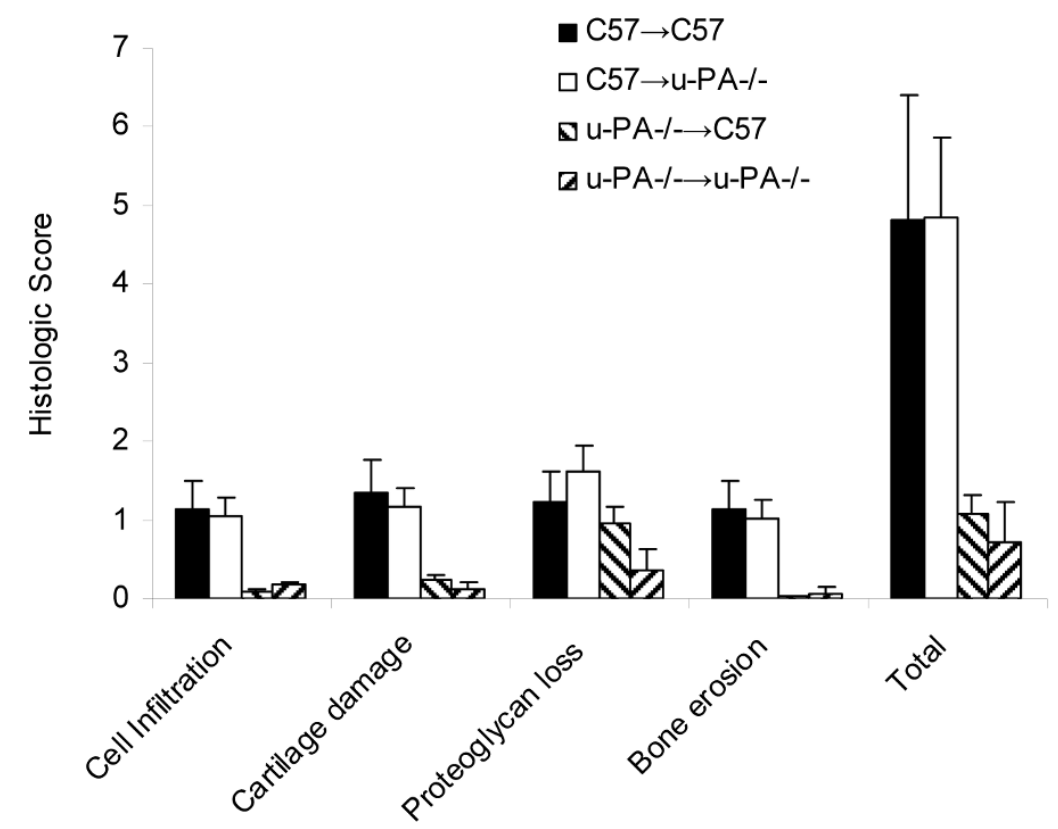

Figure 2 Histologic features of arthritis are similar in arthritis-susceptible chimeric and C57BL/6 mice. (a) H \& E staining. Magnifications $\times 100$. (b) Quantification of histologic features. C57 $\rightarrow$ C57 $\left(n=6\right.$ limbs), C57 $\rightarrow$ u-PA $A^{-/-}\left(n=10\right.$ limbs), u-PA ${ }^{-/-} \rightarrow$ C57 ( $n=6$ limbs), u-PA $A^{-/} \rightarrow \mathrm{u}-\mathrm{PA}^{-/-}(\mathrm{n}=6$ limbs). Values expressed as mean \pm standard error of the mean. 

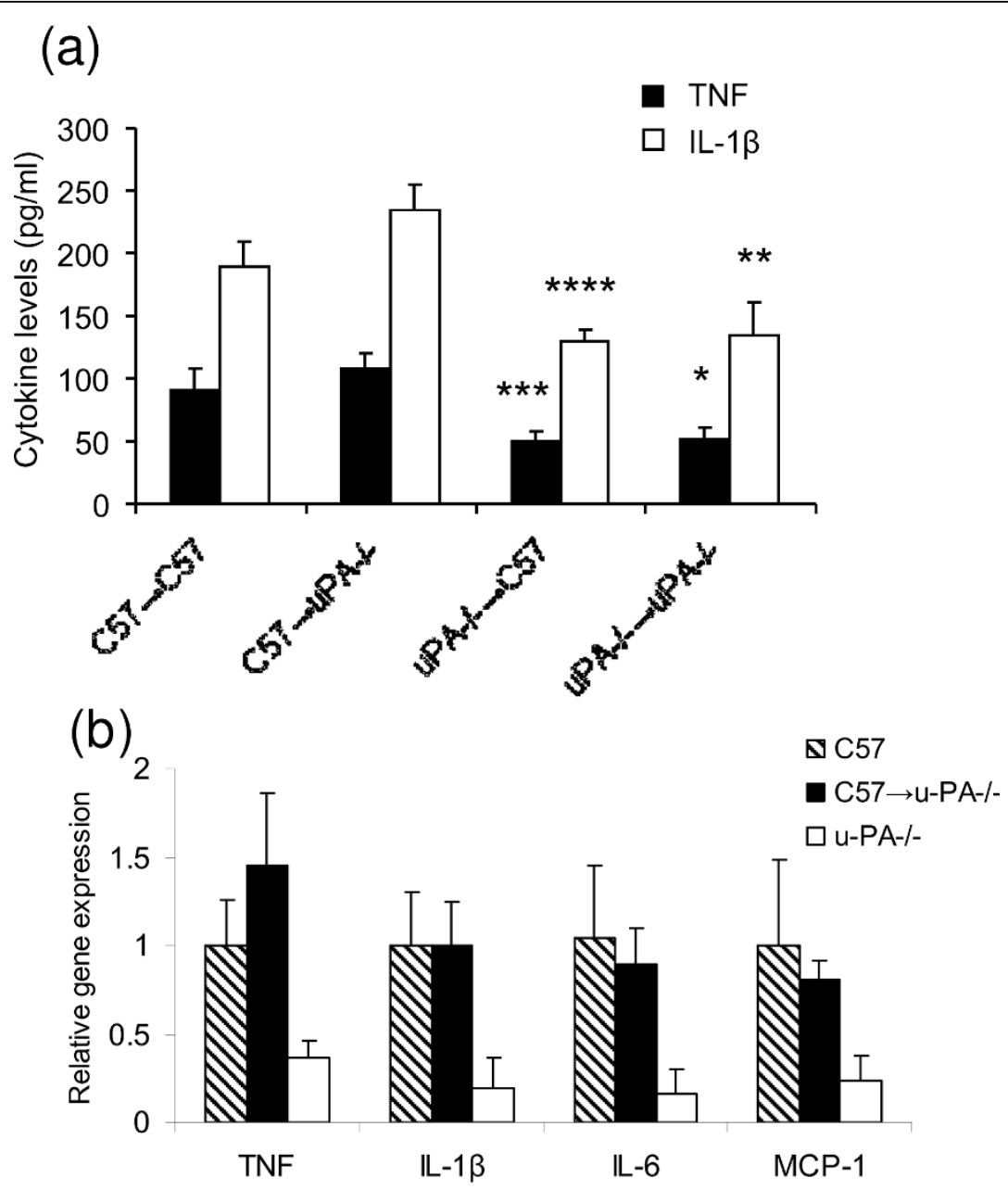

(c)
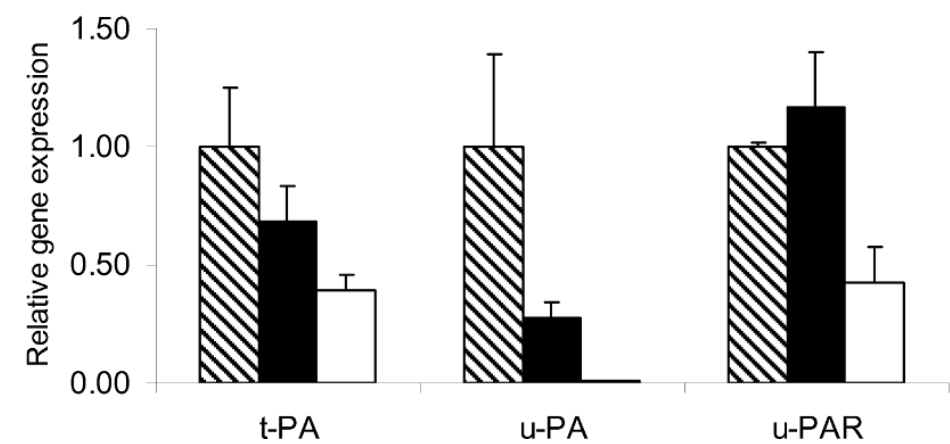

Figure 3 Mediator production and gene expression in joints from mice immunized for collagen-induced arthritis. (a) TNF and IL-1 $\beta$ levels in joint washouts following collagen-induced arthritis (CIA). TNF and IL-1 $\beta$ were measured by ELISA at sacrifice in washouts from ankle joints of C57 $\rightarrow \mathrm{C} 57(n=12), C 57 \rightarrow \mathrm{u}^{-P A^{-1}}(\mathrm{n}=16), \mathrm{u}-\mathrm{PA}^{-/-} \rightarrow \mathrm{C} 57(\mathrm{n}=11)$ and $\mathrm{u}-\mathrm{PA}^{-/} \rightarrow \mathrm{u}-\mathrm{PA}^{-/}(\mathrm{n}=9)$ mice. ${ }^{*} P<0.05,{ }^{* *} P<0.01, \mathrm{C} 57 \rightarrow$ u-PA ${ }^{-1-}$ vs. u-PA ${ }^{-1-} \rightarrow$ u-PA $^{-1-}$ mice; ${ }^{* *} P<0.05,{ }^{* * * * P}<0.01, \mathrm{u}^{*} \mathrm{PA}^{-/-} \rightarrow$ C57 vs. C57 $\rightarrow$ C57 mice. (b) TNF, IL-1 $\beta$, IL-6 and MCP-1 gene expression levels in joints following CIA ( $n=6$ for each group). C57 or C57 $\rightarrow \mathrm{u}-\mathrm{PA}^{-/-}$vs. u-PA ${ }^{-/-}$mice, $P<0.05$ for each cytokine. (c) Tissue-type plasminogen activator (t-PA), urokinase-type plasminogen activator ( $\mathrm{U}-\mathrm{PA})$ and urokinase-type plasminogen activator receptor (u-PAR) gene expression levels in joints following CIA ( $n=6$ for each group). C57 vs. u-PA ${ }^{-/}$mice, $P<0.05, \mathrm{t}-\mathrm{PA}$ and $P<0.01, \mathrm{u}-\mathrm{PAR}$; C57 $\rightarrow \mathrm{u}-\mathrm{PA}^{-/-}$vs. $\mathrm{u}-\mathrm{PA} \mathrm{A}^{-1-}$ mice, $P<0.05$, u-PAR. For (b) and (c), expression levels were normalized to an endogenous control (TATA-binding protein (TBP)) and calibrated relative to expression in C57BL/6 mice. For all, values expressed as mean level \pm standard error of the mean. 


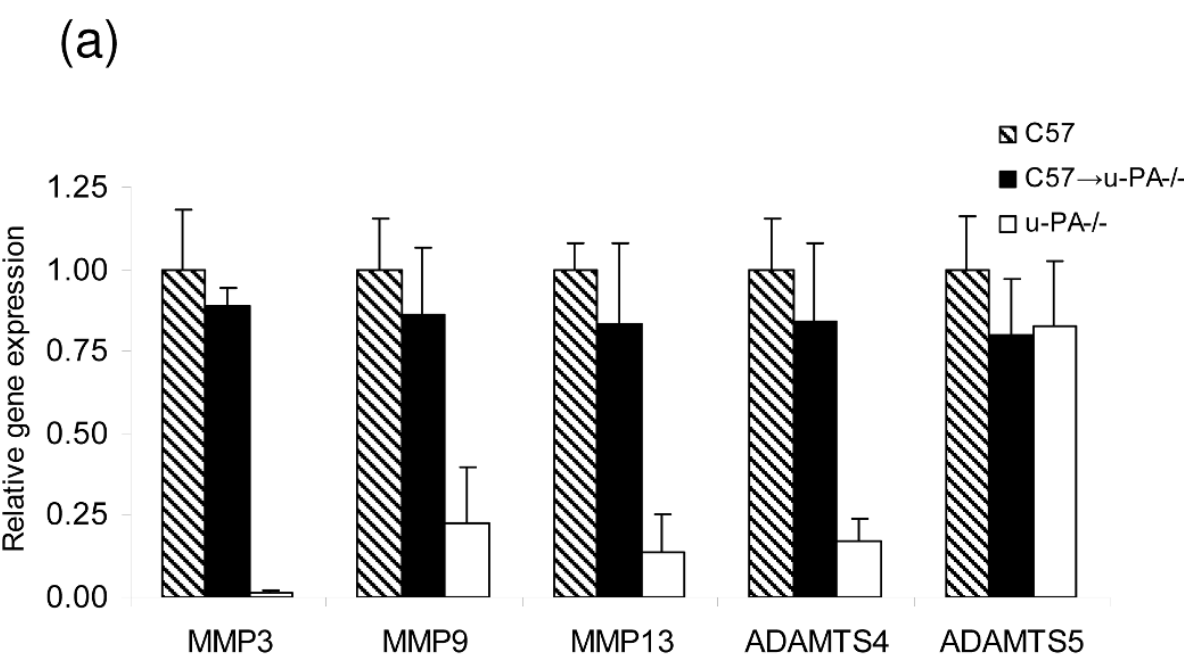

(b)

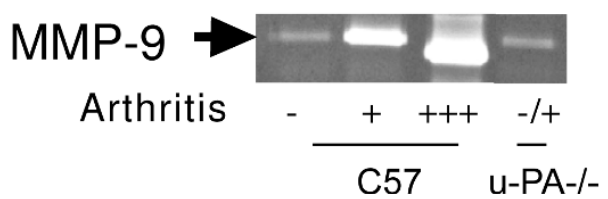

Figure 4 Matrix metalloprotease and aggrecanase gene expression and MMP-9 activity in mice immunized for collagen-induced arthritis. (a) Matrix metalloprotease (MMP)-3, MMP-9, MMP-13, ADAMTS-4 and ADAMTS-5 gene expression levels in joints following collageninduced arthritis (CIA) ( $n=6$ for each group). C57 $\rightarrow \mathrm{u}-\mathrm{PA}^{-1}$ mice, $P<0.01, \mathrm{MMP}-9$; $P<0.001$, MMP-3, ADAMTS-4; and $P<0.0001, \mathrm{MMP}-13$. $\mathrm{C} 57 \rightarrow \mathrm{u}^{-\mathrm{PA}^{-1}}$ vs. U-PA ${ }^{-1-}$ mice, $P<0.05, \mathrm{MMP}-9, \mathrm{MMP}-13$, and ADAMTS-4; $P<0.0001$, MMP-3. Expression levels were normalized to an endogenous control (TATA-binding protein (TBP)) and calibrated relative to expression in C57BL/6 mice. Values expressed as mean level \pm standard error of the mean. (b) MMP-9 levels in joint washouts, measured by zymography, from C57BL/6 and u-PA ${ }^{-/-}$mice with no arthritis (-), mild arthritis $(+)$ or severe arthritis $(+++)$. Joint washouts were pooled $(n=3)$.

the need for the induction of a T-cell response but requires LPS as a secondary stimulus to increase disease severity [16]. The TLR2 ligand, Pam-3-Cys, was used as a secondary stimulus, in place of LPS, as it gave more severe arthritis in C57BL/6 mice (average maximum clinical score $5.3 \pm 1.9$ vs. $2.1 \pm 1.3$, Pam-3-Cys vs. LPS, $P<0.05)$.

$\mathrm{u}-\mathrm{PA}^{-1-}$ mice were resistant to CAIA compared with C57BL/6 mice: $43 \%$ (three out of seven) of $\mathrm{u}-\mathrm{PA}^{-1-}$ mice developed arthritis with an average maximum clinical score of $0.6 \pm 0.2$, compared with $80 \%$ (eight out of 10 ) of $\mathrm{C} 57 \mathrm{BL} / 6$ mice with an average maximum clinical score of $5.3 \pm 1.9(P<0.05)$. In fact, the three $\mathrm{u}-\mathrm{PA}^{-/-}$ mice developed very mild arthritis, each with a maximum score of only 1.

$\mathrm{u}-\mathrm{PA}^{-/-}$mice are resistant to $\mathrm{K} / \mathrm{BxN}$ serum transfer arthritis Another immune complex-driven arthritis model is the $\mathrm{K} / \mathrm{BxN}$ serum transfer model, in which serum from $\mathrm{K} /$
BxN mice, which develop spontaneous arthritis, is able to transfer the disease to naïve mice [19]. The arthritis that develops is more severe than the CAIA model and does not require an additional stimulus. C57BL/6 mice developed rapid and severe arthritis following serum transfer, whereas $\mathrm{u}-\mathrm{PA}^{-1-}$ mice were essentially resistant (Figure 5b): $60 \%$ (three out of five) of u- $\mathrm{PA}^{-1-}$ mice developed arthritis with an average maximum clinical score of $1.2 \pm 0.5$, compared with $100 \%$ (seven out of seven) of C57BL/6 mice with an average maximum clinical score of $11.1 \pm 1.3(P<0.005)$. Once again the three $\mathrm{u}-\mathrm{PA}^{-1-}$ mice developed very mild arthritis, with a maximum score of only 2 .

By histology, C57BL/6 mice show massive cellular infiltration, cartilage damage, proteoglycan loss, bone erosion and fibrin(ogen) staining following $\mathrm{K} / \mathrm{BxN}$ serum transfer (Figure 5c, d). The joints from $\mathrm{u}-\mathrm{PA}^{-1-}$ mice, on the other hand, look relatively normal, with minimal changes in these parameters (Figure 5c, d). 


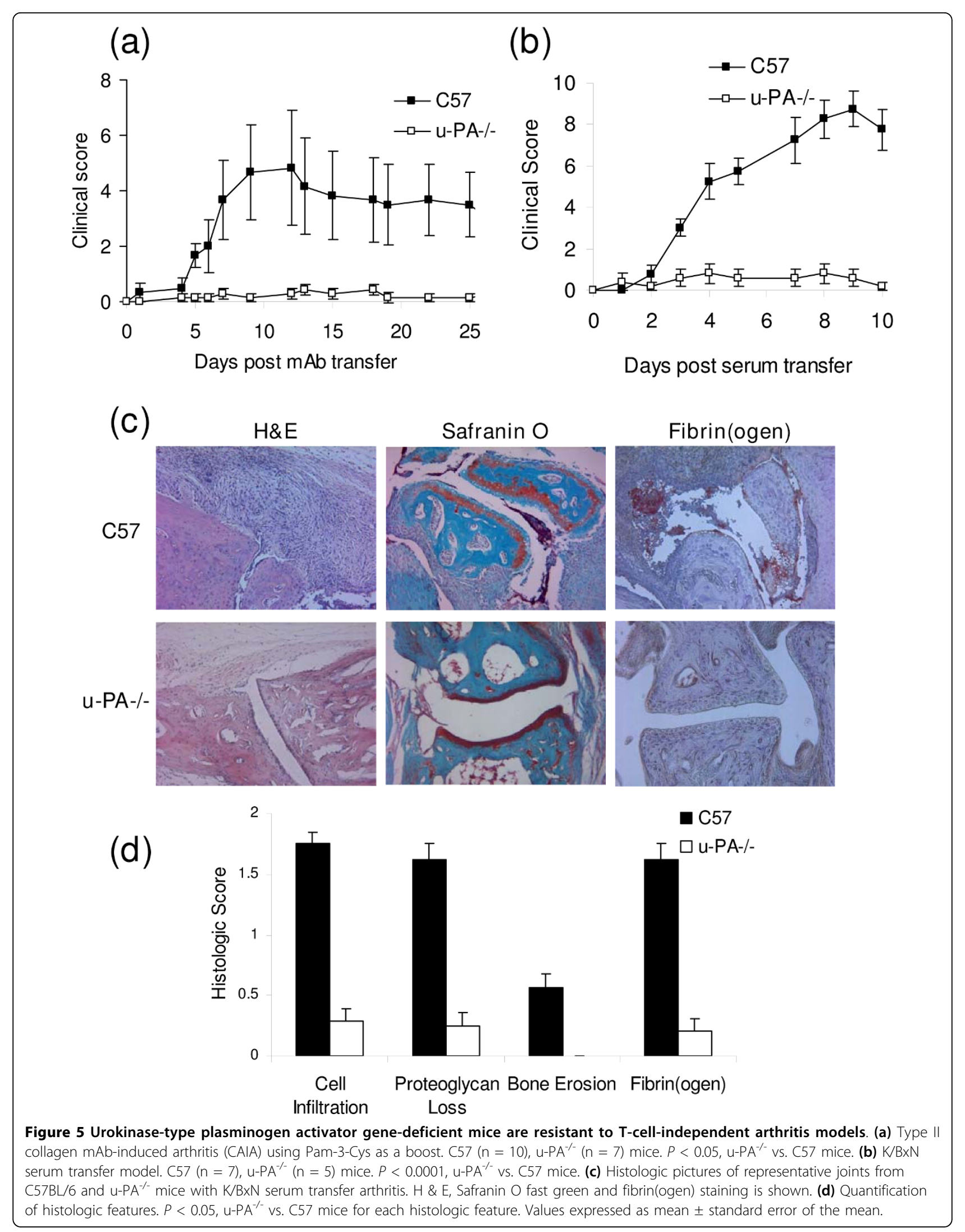


u-PA is important for the development of immune complex-mediated peritonitis

As already mentioned, the CIA model, the CAIA model and the $\mathrm{K} / \mathrm{BxN}$ serum transfer arthritis model all involve immune complex formation and deposition in joints, and, as shown above, all depend on the presence of $\mathrm{u}$ PA for disease progression. From the literature there is a report showing a requirement for $\mathrm{u}-\mathrm{PA}$ in immune complex-driven lung inflammation [28]. In order to explore further the proposed involvement of $\mathrm{u}-\mathrm{PA}$ in immune complex-dependent inflammation we required a model where we could assess u-PA dependence following direct application of an immune complex. As the immune-complex arthritis model is induced using an intra-articular injection [29], we decided against this as such an injection leads to more severe arthritis in $\mathrm{u}$ $\mathrm{PA}^{-/-}$mice $[12,13]$, possibly due to the trauma involved. For this reason, and also because the peritoneal cavity is a convenient site for the isolation and quantification of both extravasated inflammatory cells and also of inflammatory mediators, we used the immune complexmediated peritonitis model [20].

We have previously shown that $\mathrm{u}-\mathrm{PA}$ was not required for the development of murine peritonitis, as measured by neutrophil and macrophage infiltration, using either the nonspecific irritant, thioglycolate, as a stimulus, or an antigen (methylated BSA)-specific stimulus [30]. The lack of effect of u-PA deficiency with these stimuli therefore gave us the opportunity to once again see whether there is a particular association between immune complexes and u-PA.

In $\mathrm{u}-\mathrm{PA}^{-1-}$ mice there were significantly fewer neutrophils present in their peritoneal cavity compared with C57BL/6 mice 4 hours post initiation of immune complex-mediated neutrophilia $(P<0.01)$ (Figure 6a). The levels of the chemokines, KC and MIP-2, shown previously to be produced following immune complexinduced neutrophilia in the peritoneal cavity [20], were measured. KC $(P<0.01)$ and MIP-2 $(P<0.01)$ (Figure $6 \mathrm{~b})$ levels were lower in the peritoneal exudate fluid of $\mathrm{u}-\mathrm{PA}^{-1-}$ mice compared with the levels in C57BL/6 mice. This suggests that $\mathrm{u}-\mathrm{PA}$ is involved in the initiation of immune complex-mediated inflammatory response in the peritoneal cavity leading to the production of chemokines and recruitment of neutrophils.

There is evidence that immune complexes induce the bioactive complement component, $\mathrm{C} 5 \mathrm{a}$ anaphylatoxin, which, in turn, interacts with the $\mathrm{C} 5 \mathrm{aR}$, thus reducing the threshold for Fc $\gamma$-receptor activation and leading to the recruitment of neutrophils into the peritoneal cavity [20,31]. Also, ablation of C5aR signaling abrogates neutrophil recruitment and production of KC and MIP-2 [20]. Therefore, in order to determine whether u-PA might be required downstream of $\mathrm{C} 5 \mathrm{a}$ signaling in acute

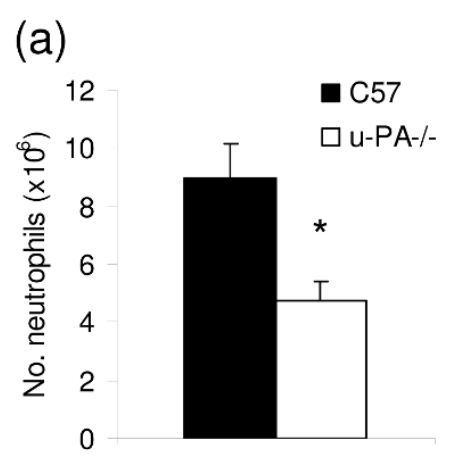

(b)
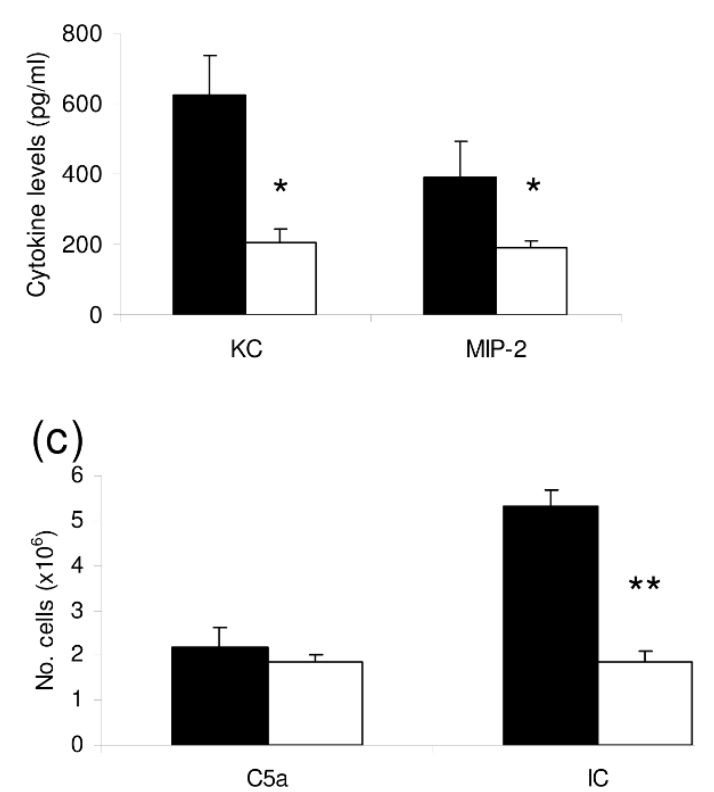

Figure 6 Urokinase-type plasminogen activator is important for the development of immune complex-mediated, but not C5a-mediated, neutrophilia. (a) Number of neutrophils in the peritoneal exudate of C57BL/6 $(n=12)$ and $\mathrm{u}_{-\mathrm{PA}^{-/-}}(\mathrm{n}=12)$ mice 4 hours post injection of ovalbumin (OVA) intravenously and anti-OVA intraperitoneally. (b) Levels of KC and MIP-2 in peritoneal exudate fluid of C57BL6 $(n=8)$ and u-PA ${ }^{-/-}$mice $(n=8) 4$ hours post OVA/ anti-OVA injection, as measured by ELISA. (c) Total cell number in the peritoneal exudate 2 hours post intraperitoneal injection of $\mathrm{C} 5 \mathrm{a}$ or immune complex ( $n=6$ per group). Values expressed as mean \pm standard error of the mean. ${ }^{*} P<0.01,{ }^{*} P<0.001, \mathrm{C} 57 \mathrm{vs}$. U-PA ${ }^{-1-}$ mice.

peritonitis, C5a itself was given intraperitoneally and the inflammatory response was followed. A 2-hour time point was chosen for measurement of the neutrophilia based on published literature [32]. Following intraperitoneal injection of C5a there was no significant difference in the number of recoverable peritoneal exudate cells between $\mathrm{u}-\mathrm{PA}^{-/-}$and C57BL/6 mice (Figure 6c). As a control, once again, stimulation with the immune complex led to an increased number of recoverable 
peritoneal exudate cells from C57BL/6 mice, with a significantly reduced number of exudate cells recoverable from $\mathrm{u}-\mathrm{PA}^{-1-}$ mice 2 hours post challenge $(P<0.001$; Figure $6 \mathrm{c}$ ). Injection of saline alone did not induce significant numbers of neutrophils at this time point (data not shown). Since, from the data above, C5a-triggered neutrophilia in the peritoneal cavity does not require $\mathrm{u}$ $\mathrm{PA}$, it suggests that the u-PA involvement in immune complex-mediated neutrophilia may not be downstream of C5a signaling.

\section{Discussion}

We and other workers have previously shown that $\mathrm{u}$ $\mathrm{PA}^{-1-}$ mice develop very mild CIA $[14,15]$, whereas these same mice develop more severe AIA [12] and methylated BSA/IL-1 arthritis [13] compared with C57BL/6 mice. Both the AIA and mBSA/IL-1 models are induced using an intra-articular injection resulting in monoarticular arthritis in the injected joint. In these monoarticular models, the enhanced disease severity seen in $\mathrm{u}-\mathrm{PA}^{-1-}$ mice correlated with increased fibrin(ogen) deposition in the joint $[12,13]$. The beneficial role of $\mathrm{u}-\mathrm{PA}$ in these monoarticular models is thus likely to be in fibrinolysis. The deleterious role of $\mathrm{u}-\mathrm{PA}$ is less clear in CIA, with a possible effect on T-cell activation, cell migration and/or tissue destruction $[1,2]$. Using several polyarticular arthritis models, which all involve immune complexes and $\mathrm{C} 5$ activation [33,34], we showed here that $\mathrm{u}-\mathrm{PA}$ is important for full disease expression.

Based on in vitro studies, several different cell types present in arthritic joints have been proposed to be potential sources of u-PA [10]. For CIA development, $u$ PA derived from a bone marrow cell(s), but not from a nonbone marrow-derived cell(s), was shown to be required for the full development of disease. A number of different bone marrow-derived cell types are required for CIA development, but lymphocytes are not required for the CAIA and $\mathrm{K} / \mathrm{BxN}$ serum transfer models [35], suggesting it could be the myeloid cells that are producing u-PA required for arthritis development. Of note, the monocyte/macrophage was one cell type proposed as a source of u-PA in arthritis [10]. Gene expression of several major proinflammatory and destructive mediators were similar in the joints of CIA-susceptible chimeric mice and wild-type mice, but increased compared with CIA-resistant $\mathrm{u}-\mathrm{PA}^{-1-}$ mice. Activation of procollagenases is a key control point in cartilage collagen breakdown, and it has been shown, at least in vitro, that the PA/plasmin system can activate MMPs [36].

It has previously been reported that $\mathrm{u}-\mathrm{PA}$ was required for $\mathrm{T}$-cell proliferation and activation in vitro, and that its absence led to a reduced T-helper type-1polarized profile of cytokines [37]. We found T cells from CII-primed $\mathrm{u}-\mathrm{PA}^{-1-}$ mice had a reduced proliferative response to CII in vitro compared with wild-type mice although the in vivo antibody response to $\mathrm{CII}$ was no different in $\mathrm{u}-\mathrm{PA}^{-1-}$ mice, suggesting normal immune complex formation [14]. Here we found $u-$ $\mathrm{PA}^{-1-}$ mice to also be resistant to the CAIA and $\mathrm{K} / \mathrm{BxN}$ serum transfer models, which are $\mathrm{T}$-cell-independent models, at least for disease induction [16], suggesting the defect in the antigen-specific T-cell response is unlikely to be solely responsible for the resistance of $\mathrm{u}-\mathrm{PA}^{-1-}$ mice to CIA [14]. In these models, where u-PA is deleterious, its role may be in migration of leukocytes to the joints. The u-PA/u-PAR system has been implicated in migration/chemotaxis of inflammatory cells [38-43], although when using either thioglycolate or mBSA as the stimulus we found no difference in the inflammatory cell influx into the peritoneal cavity of $\mathrm{u}-\mathrm{PA}^{-1-}$ mice compared with C57BL/6 mice [30], suggesting that $\mathrm{u}$ PA is not always required for cell migration into tissues.

Another possible role for u-PA may be in the development of immune complex-mediated inflammation. The CIA, CAIA and the $\mathrm{K} / \mathrm{BxN}$ serum transfer models all involve immune complex formation and deposition in joints, and u-PA has been reported to be required in an immune complex-induced lung inflammation model [28]. Whilst immune complexes have been reported in AIA [44], this model does not require B cells [45], and thus, disease development is not dependent on immune complex formation. Utilizing the peritoneal cavity once again we showed here that $\mathrm{u}$-PA does appear to be required for immune complex-mediated neutrophilia. Immune complexes have been shown to activate the complement system leading to the generation of C5a in this peritonitis model, which then initiates the inflammatory cascade - both through direct C5aR-mediated effector functions on infiltrating and resident cells, and, also indirectly, by shifting the balance between activating (Fc $\gamma$ RI and Fc $\gamma$ RIII) and inhibitory (Fc $\gamma$ RIIB) Fc $\gamma$ receptors on resident cells toward an inflammatory phenotype [20]; also, ablation of C5aR signaling abrogates neutrophil recruitment and production of KC and MIP-2 in the same model [20]. By analogy, the proposed setting of a threshold for Fc $\gamma$-receptor activation in immune complex-mediated disease by $\mathrm{C} 5 \mathrm{a}$ [20] could be occurring in the CIA, CAIA and $\mathrm{K} / \mathrm{BxN}$ arthritis models, which are all $C 5$ a dependent $[33,34]$.

As regards possible u-PA involvement in immune complex-induced lung inflammation [28], it was proposed that $\mathrm{u}-\mathrm{PA} / \mathrm{u}-\mathrm{PAR}$ activation was necessary for C5aR signaling in alveolar macrophages, which, in turn, modulated the functional balance of the $\mathrm{F} c \gamma$ receptors. Also, the presence of u-PA was shown to increase C5ainduced MIP-2 and TNF $\alpha$ production by the alveolar macrophage MH-S cell line in vitro, and blockade of $\mathrm{u}$ PAR on the cell surface completely prevented u-PA- 
induced enhancement of MIP-2 and TNF $\alpha$ release from C5a-stimulated $\mathrm{MH}-\mathrm{S}$ cells [28]. Based on these findings it was suggested that $\mathrm{u}-\mathrm{PA} / \mathrm{u}-\mathrm{PAR}$ activation is important for effective C5a/C5aR signaling in this model, and perhaps others. We found following direct C5a administration, however, that $\mathrm{u}-\mathrm{PA}$ is not required for neutrophil migration into the peritoneal cavity, suggesting that $\mathrm{u}$-PA may rather be important for the generation of adequate $\mathrm{C} 5 \mathrm{a}$ for activation/signaling downstream of immune complex activation rather than for C5a signaling itself in immune complex-driven peritonitis. In the absence of $\mathrm{u}-\mathrm{PA}$, lower levels of the chemokines $\mathrm{KC}$ and MIP-2 were noted in the immune complex-driven peritonitis model; it is therefore possible that there is reduced chemotaxis of neutrophils rather than there being an intrinsic defect in the ability of the cells to migrate per se.

Apart from signaling via its receptor, u-PA also cleaves plasminogen to form plasmin [1], which can activate complement [46]. Plasminogen ${ }^{-/-}$mice have been shown to be resistant to both CIA and CAIA [15]. The relative contribution of $\mathrm{u}-\mathrm{PA}$ signaling via its receptor and/or via the generation of plasmin in immune complex-mediated inflammatory responses is currently being examined as it may be model specific.

\section{Conclusions}

u-PA is required for the full development of arthritis models involving immune complex formation and deposition - namely, the CIA, CAIA and K/BxN serum transfer models - as opposed to the monoarticular models - AIA and mBSA/IL-1. The cellular source of u-PA required for arthritis development, at least for the CIA model, is bone marrow derived and possibly of myeloid origin. From studies utilizing the peritoneal cavity and from the work of others in the lung [28], it appears that $\mathrm{u}-\mathrm{PA}$ is important in other immune complex-mediated inflammatory reactions. As mentioned, any connection to complement involvement and associated mechanisms require further analysis. Given that a number of autoimmune diseases are immune complex mediated, u-PA may prove a suitable therapeutic target for such diseases.

\footnotetext{
Abbreviations

AIA: antigen-induced arthritis; BSA: bovine serum albumin; CAIA: type ॥ collagen mAb-induced arthritis; CII: type II collagen; CIA: collagen-induced arthritis; DMEM: Dulbecco's modified Eagle's medium; ELISA: enzyme-linked immunosorbent assay; H \& E: hematoxylin and eosin; IL: interleukin; KC: Keratinocyte-derived chemokine; LPS: lipopolysaccharide; mAb: monoclonal antibody; MIP-2: macrophage inflammatory protein-2; MMP: matrix metalloprotease; PA: plasminogen activator; PBS: phosphate-buffered saline; PCR: polymerase chain reaction; t-PA: tissue-type plasminogen activator; TNF:

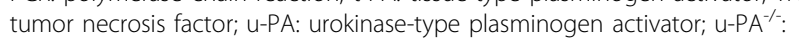
urokinase-type plasminogen activator gene deficient; u-PAR: urokinase-type plasminogen activator receptor.
}

\section{Acknowledgements}

The authors thank P Carmeliet for the mice, and J Davis for their maintenance and care. This work was supported by a grant and a Senior Principal Research Fellowship (to JAH) from the National Health and Medical Research Council of Australia.

\section{Author details}

${ }^{1}$ Arthritis and Inflammation Research Centre, Department of Medicine, The University of Melbourne, Parkville, Melbourne, Victoria 3010, Australia. ${ }^{2}$ Cooperative Research Centre for Chronic Inflammatory Diseases, The University of Melbourne, Parkville, Melbourne, Victoria 3010, Australia.

\section{Authors' contributions}

ADC conceived the study, and participated in its design and coordination and drafted the manuscript. CMDN carried out the K/BXN serum transfer model and immune complex-mediated peritonitis studies. ELB and ALT carried out the chimera studies. RV carried out the zymography. KJW and SKB carried out the gene and protein studies. JCL participated in the immunohistochemistry. JAH conceived the study, and participated in its design and helped to draft the manuscript. All authors read and approved the final manuscript.

\section{Competing interests}

The authors declare that they have no competing interests.

Received: 8 December 2009 Revisions requested: 8 January 2010 Revised: 1 February 2010 Accepted: 2 March 2010

Published: 2 March 2010

\section{References}

1. Irigoyen JP, Munoz-Canoves P, Montero L, Koziczak M, Nagamine Y: The plasminogen activator system: biology and regulation. Cell Mol Life Sci 1999, 56:104-132.

2. Busso N, Hamilton JA: Extravascular coagulation and the plasminogen activator/plasmin system in rheumatoid arthritis. Arthritis Rheum 2002, 46:2268-2279.

3. Busso N, Peclat V, So A, Sappino AP: Plasminogen activation in synovial tissues: differences between normal, osteoarthritis, and rheumatoid arthritis joints. Ann Rheum Dis 1997, 56:550-557.

4. Hamilton JA, Stanley ER, Burgess AW, Shadduck RK: Stimulation of macrophage plasminogen activator activity by colony-stimulating factors. J Cell Physiol 1980, 103:435-445.

5. Hamilton JA, Slywka J: Stimulation of human synovial fibroblast plasminogen activator production by mononuclear cell supernatants. J Immunol 1981, 126:851-855.

6. Leizer T, Clarris BJ, Ash PE, van Damme J, Saklatvala J, Hamilton JA: Interleukin-1 beta and interleukin-1 alpha stimulate the plasminogen activator activity and prostaglandin E2 levels of human synovial cells. Arthritis Rheum 1987, 30:562-566.

7. Campbell IK, Piccoli DS, Butler DM, Singleton DK, Hamilton JA: Recombinant human interleukin-1 stimulates human articular cartilage to undergo resorption and human chondrocytes to produce both tissue- and urokinase-type plasminogen activator. Biochim Biophys Acta 1988, 967:183-194.

8. Campbell IK, Last K, Novak U, Lund LR, Hamilton JA: Recombinant human interleukin-1 inhibits plasminogen activator inhibitor-1 (PAI-1) production by human articular cartilage and chondrocytes. Biochem Biophys Res Commun 1991, 174:251-257.

9. Hamilton JA, Hart PH, Leizer T, Vitti GF, Campbell IK: Regulation of plasminogen activator activity in arthritic joints. J Rheumatol Supp/ 1991, 27:106-109.

10. Hamilton JA, Campbell IK, Wojta J, Cheung D: Plasminogen activators and their inhibitors in arthritic disease. Ann N Y Acad Sci 1992, 667:87-100.

11. Hamilton JA, Cheung D, Filonzi EL, Piccoli DS, Wojta J, Gallichio M, McGrath K, Last K: Independent regulation of plasminogen activator inhibitor 2 and plasminogen activator inhibitor 1 in human synovial fibroblasts. Arthritis Rheum 1992, 35:1526-1534.

12. Busso N, Peclat V, Van Ness K, Kolodziesczyk E, Degen J, Bugge T, So A: Exacerbation of antigen-induced arthritis in urokinase-deficient mice. $J$ Clin Invest 1998, 102:41-50. 
13. Yang YH, Carmeliet $P$, Hamilton JA: Tissue-type plasminogen activator deficiency exacerbates arthritis. J Immunol 2001, 167:1047-1052.

14. Cook AD, Braine EL, Campbell IK, Hamilton JA: Differing roles for urokinase and tissue-type plasminogen activator in collagen-induced arthritis. Am J Pathol 2002, 160:917-926.

15. Li J, Ny A, Leonardsson G, Nandakumar KS, Holmdahl R, Ny T: The plasminogen activator/plasmin system is essential for development of the joint inflammatory phase of collagen type II-induced arthritis. Am J Pathol 2005, 166:783-792.

16. Nandakumar KS, Backlund J, Vestberg M, Holmdahl R: Collagen type II (CII)specific antibodies induce arthritis in the absence of $\mathrm{T}$ or $\mathrm{B}$ cells but the arthritis progression is enhanced by Cll-reactive T cells. Arthritis Res Ther 2004, 6:R544-R550.

17. Wang J, Fathman JW, Lugo-Villarino G, Scimone L, von Andrian U, Dorfman DM, Glimcher LH: Transcription factor T-bet regulates inflammatory arthritis through its function in dendritic cells. J Clin Invest 2006, 116:414-421

18. Mitamura M, Nakano N, Yonekawa T, Shan L, Kaise T, Kobayashi T, Yamashita K, Kikkawa H, Kinoshita M: T cells are involved in the development of arthritis induced by anti-type II collagen antibody. Int Immunopharmacol 2007, 7:1360-1368.

19. Kouskoff V, Korganow AS, Duchatelle V, Degott C, Benoist C, Mathis D: Organ-specific disease provoked by systemic autoimmunity. Cell 1996, 87:811-822.

20. Godau J, Heller T, Hawlisch H, Trappe M, Howells E, Best J, Zwirner J, Verbeek JS, Hogarth PM, Gerard C, Van Rooijen N, Klos A, Gessner JE, Kohl J: C5a initiates the inflammatory cascade in immune complex peritonitis. J Immunol 2004, 173:3437-3445.

21. Cook $A D$, Braine $E L$, Hamilton JA: The phenotype of inflammatory macrophages is stimulus dependent: implications for the nature of the inflammatory response. J Immunol 2003, 171:4816-4823.

22. Cook AD, Braine EL, Hamilton JA: Stimulus-dependent requirement for granulocyte-macrophage colony-stimulating factor in inflammation. $J$ Immunol 2004, 173:4643-4651.

23. Bozinovski S, Jones J, Beavitt SJ, Cook AD, Hamilton JA, Anderson GP: Innate immune responses to LPS in mouse lung are suppressed and reversed by neutralization of GM-CSF via repression of TLR-4. Am J Physiol Lung Cell Mol Physiol 2004, 286:L877-L885.

24. Fleetwood AJ, Lawrence T, Hamilton JA, Cook AD: Granulocytemacrophage colony-stimulating factor (CSF) and macrophage CSFdependent macrophage phenotypes display differences in cytokine profiles and transcription factor activities: implications for CSF blockade in inflammation. J Immunol 2007, 178:5245-5252.

25. Campbell IK, Rich MJ, Bischof RJ, Dunn AR, Grail D, Hamilton JA: Protection from collagen-induced arthritis in granulocyte-macrophage colonystimulating factor-deficient mice. J Immunol 1998, 161:3639-3644.

26. Campbell IK, Hamilton JA, Wicks IP: Collagen-induced arthritis in C57BL/6 $(\mathrm{H}-2 \mathrm{~b})$ mice: new insights into an important disease model of rheumatoid arthritis. Eur J Immunol 2000, 30:1568-1575.

27. Nandakumar KS, Svensson L, Holmdahl R: Collagen type II-specific monoclonal antibody-induced arthritis in mice: description of the disease and the influence of age, sex, and genes. Am J Pathol 2003, 163:1827-1837.

28. Shushakova N, Eden G, Dangers M, Zwirner J, Menne J, Gueler F, Luft FC, Haller H, Dumler I: The urokinase/urokinase receptor system mediates the IgG immune complex-induced inflammation in lung. J Immunol 2005 175:4060-4068

29. Blom $A B$, van Lent $P L$, Holthuysen $A E$, Berg van den WB: Immune complexes, but not streptococcal cell walls or zymosan, cause chronic arthritis in mouse strains susceptible for collagen type II auto-immune arthritis. Cytokine 1999, 11:1046-1056.

30. Cook AD, Vlahos R, Massa CM, Braine EL, Lenzo JC, Turner AL, Way KJ, Hamilton JA: The effect of tissue type-plasminogen activator deletion and associated fibrin(ogen) deposition on macrophage localization in peritoneal inflammation. Thromb Haemost 2006, 95:659-667.

31. Gerard NP, Gerard C: The chemotactic receptor for human C5a anaphylatoxin. Nature 1991, 349:614-617.

32. Vlasenko LP, Melendez AJ: A critical role for sphingosine kinase in anaphylatoxin-induced neutropenia, peritonitis, and cytokine production in vivo. J Immunol 2005, 174:6456-6461.
33. Wang $Y$, Kristan J, Hao L, Lenkoski CS, Shen Y, Matis LA: A role for complement in antibody-mediated inflammation: C5-deficient DBA/1 mice are resistant to collagen-induced arthritis. J Immunol 2000, 164:4340-4347.

34. Ji H, Ohmura K, Mahmood U, Lee DM, Hofhuis FM, Boackle SA, Takahashi K, Holers VM, Walport M, Gerard C, Ezekowitz A, Carroll MC, Brenner M, Weissleder R, Verbeek JS, Duchatelle V, Degott C, Benoist C, Mathis D: Arthritis critically dependent on innate immune system players. Immunity 2002, 16:157-168

35. Nandakumar KS, Holmdahl R: Antibody-induced arthritis: disease mechanisms and genes involved at the effector phase of arthritis. Arthritis Res Ther 2006, 8:223.

36. Milner JM, Elliott SF, Cawston TE: Activation of procollagenases is a key control point in cartilage collagen degradation: interaction of serine and metalloproteinase pathways. Arthritis Rheum 2001, 44:2084-2096.

37. Gyetko MR, Libre EA, Fuller JA, Chen GH, Toews G: Urokinase is required for T lymphocyte proliferation and activation in vitro. J Lab Clin Med 1999, 133:274-288.

38. Boyle MD, Chiodo VA, Lawman MJ, Gee AP, Young M: Urokinase: a chemotactic factor for polymorphonuclear leukocytes in vivo. J Immunol 1987, 139:169-174.

39. Vakili J, Standker L, Detheux M, Vassart G, Forssmann WG, Parmentier M: Urokinase plasminogen activator and plasmin efficiently convert hemofiltrate CC chemokine 1 into its active. J Immunol 2001, 167:3406-3413.

40. Gyetko MR, Sud S, Kendall T, Fuller JA, Newstead MW, Standiford TJ: Urokinase receptor-deficient mice have impaired neutrophil recruitment in response to pulmonary Pseudomonas aeruginosa infection. J Immunol 2000, 165:1513-1519.

41. Gyetko MR, Sud S, Sonstein J, Polak T, Sud A, Curtis JL: Antigen-driven lymphocyte recruitment to the lung is diminished in the absence of urokinase-type plasminogen activator (UPA) receptor, but is independent of uPA. J Immunol 2001, 167:5539-5542.

42. Rijneveld AW, Levi M, Florquin S, Speelman $P$, Carmeliet $P$, Poll van Der $T$ Urokinase receptor is necessary for adequate host defense against pneumococcal pneumonia. J Immunol 2002, 168:3507-3511.

43. Gyetko MR, Aizenberg D, Mayo-Bond L: Urokinase-deficient and urokinase receptor-deficient mice have impaired neutrophil antimicrobial activation in vitro. J Leukoc Biol 2004, 76:648-656.

44. Fischetti F, Durigutto P, Macor P, Marzari R, Carretta R, Tedesco F: Selective therapeutic control of $\mathrm{C} 5 \mathrm{a}$ and the terminal complement complex by anti-C5 single-chain Fv in an experimental model of antigen-induced arthritis in rats. Arthritis Rheum 2007, 56:1187-1197.

45. Wong PK, Quinn JM, Sims NA, van Nieuwenhuijze A, Campbell IK, Wicks IP: Interleukin-6 modulates production of T lymphocyte-derived cytokines in antigen-induced arthritis and drives inflammation-induced osteoclastogenesis. Arthritis Rheum 2006, 54:158-168.

46. Schaiff WT, Eisenberg PR: Direct induction of complement activation by pharmacologic activation of plasminogen. Coron Artery Dis 1997, 8:9-18.

doi:10.1186/ar2946

Cite this article as: Cook et al:: Urokinase-type plasminogen activator and arthritis progression: role in systemic disease with immune complex involvement. Arthritis Research \& Therapy 2010 12:R37.

\section{Submit your next manuscript to BioMed Central and take full advantage of:}

- Convenient online submission

- Thorough peer review

- No space constraints or color figure charges

- Immediate publication on acceptance

- Inclusion in PubMed, CAS, Scopus and Google Scholar

- Research which is freely available for redistribution

Submit your manuscript at www.biomedcentral.com/submit
C Biomed Central 